\title{
СРАВНИТЕЛЬНЫЙ АНАЛИЗ ПРОМЫШЛЕННЫХ ПОЛИТИК СУБЪЕКТОВ ПРИВОЛЖСКОГО ФЕДЕРАЛЬНОГО ОКРУГА
}

\section{(c) 2020 Шарафутдинова Лилия Ражаповна}

аспирант кафедры экономики и управления предприятиями и производственными комплексами Санкт-Петербургский государственный экономический университет, Россия, Санкт-Петербург E-mail: liliya.sharafutdinova22@gmail.com

Проблема повышения эффективности российской экономики неразрывно связана с корректностью формирования и реализации промышленной политики на различных уровнях управления. В статье проведены результаты анализа промышленных политик субъектов Приволжского федерального округа на основе показателей развития промышленности, выявлены проблемы и сформированы рекомендации по их решению.

Ключевые слова: промышленная политика, Приволжский федеральный округ, высокотехнологичная продукция, регион

В соответствии со ст. 3 Федерального закона от 31 декабря 2014 г. № 488 «О промышленной политике в Российской Федерации», под промышленной политикой понимается «комплекс правовых, экономических, организационных и иных мер, направленных на развитие промышленного потенциала РФ, обеспечение производства конкурентоспособной промышленной продукции» [1]. Исходя из установленных на общегосударственном уровне принципов, на уровне регионов формируется региональная промышленной политика, рассматриваемая как комплекс мер, направленный на развитие промышленного потенциала региона, решение проблем региона, обеспечение конкурентоспособности промышленной продукции, достижение целей региональной и федеральной промышленной политик. Взаимоувязанность целей, задач, приоритетов и механизмов реализации политики каждого субъекта с целями промышленной политики Российской Федерации является неотъемлемым условием обеспечения конкурентоспособности национальной промышленности. К документам нормативного обеспечения региональной промышленной политики относятся законы субъектов РФ «О промышленной политики», «Программа развития промышленности», «Комплексный инвестиционный план», иные региональные отраслевые нормативно-правовые документы, например, государственная программа Республики Башкортостан «Развитие промышленности и повышение ее конкурентоспособности в Республике Башкортостан» и др.
В 2000 году Указом Президента Российской Федерации «О полномочном представительстве Президента РФ в Федеральном округе» от 13 мая 2000 года № 849 был сформирован новый уровень территориального деления - федеральный округ, целями которого являются комплексное развитие инфраструктуры округа, обеспечение потребностей населения, укрепление взаимосвязей между субъектами округа, другими округами страны, приграничными территориями. Все это способствует упорядочению управления и контроля субъектами страны, организации власти в целях решения политических, экономических, социальных проблем [10].

Одним из промышленно развитых федеральных округов является Приволжский федеральный округ (ПФО), расположенный на востоке Европейской части РФ. ПФО - второй по численности населения округ Российской Федерации после Центрального (на 1 января 2020 года 29287 683 чел., из которых около $72 \%$ городского и 28\%). В состав округа входят 14 субъектов: Республика Башкортостан, Республика Мордовия, Республика Марий Эл, Республика Татарстан, Чувашская Республика, Удмуртская Республика, Пермский край, Нижегородская область, Кировская область, Оренбургская область, Самарская область, Ульяновская область, Саратовская область, Пензенская область. Административным центром является Нижний Новгород. ПФО характеризуется диверсифицированной структурой экономики и высоким инновационным потенциалом.

Промышленное развитие субъектов ПФО осуществляется в соответствии с приоритета- 
ми пространственного развития Российской Федерации, целями промышленных политик, зафиксированных в нормативно-правовой документации [2,3,4,5,6]. Федеральным законом от 31 декабря 2014 г. № 488 определены следующие направления промышленного производства: добыча полезных ископаемых, обрабатывающее производство, обеспечение электрической энергией, газом и паром, кондиционирование воздуха, водоснабжение, водоотведение, организация сбора и утилизации отходов, а также ликвидация загрязнений.

Анализ промышленной политики субъектов ПФО построен на основе оценки показателей, характеризующих развитие промышленности: валовый региональный продукт (ВРП); индекс промышленного производства (ИПП); объем отгруженной продукции собственного производства; индекс производительности труда; объем привлеченных инвестиций в регион; число инвестиционных проектов, ориентированных на развитие промышленного потенциала региона; доля продукции высокотехнологичных и наукоемких отраслей в ВРП.

В структуре валовой добавленной стоимости ПФО сфера промышленности является преобладающей (около 40\%). На рисунке 1 представлена динамика индексов физического объема валового внутреннего продукта РФ и ВРП ПФО за период 2012-2017 гг.

Динамика индексов показывает более интенсивный рост ВРП ПФО по сравнению с ВВП РФ. Отрицательная динамика в 2015 году по обоим показателям: 2,7\% - ВВП РФ, 1,9\% - ВРП ПФО связана с оттоком капитала, падением инвестиционного спроса, снижением уровня реального дохода населения.

К основным отраслями специализации ПФО относятся: машиностроение, химическая и нефтехимическая промышленности, топливноэнергетический комплекс, легкая и пищевая промышленность, металлообработка.

Число предприятий и организаций в 2018 году составило 721150 ед., что на 3,4\% меньше по сравнению с 2017 г. Из них по видам экономической деятельности к предприятиям по добыче полезных ископаемых относятся 2995 ед., из которых 18\% расположено в Республике Башкортостан и Республике Татарстан, 13\% в Оренбургской и Самарской областях; по обрабатывающему производству 59990 ед.- 13\% в Нижегородской области.

В промышленной сфере ПФО наибольший удельный вес приходится на обрабатывающие производства (72\%), затем на добычу полезных ископаемых (20\%). В 2018 году по объему отгруженных товаров лучшие показатели демонстрировали:

- по добыче полезных ископаемых: Республика Татарстан (26\%), Оренбургская область (21\%), Пермский край (15\%), Самарская область (14\%), Республика Башкортостан (12\%).

- по обрабатывающим производствам: Республика Татарстан (21\%), Нижегородская область (15\%), Республика Башкортостан (14\%), Пермский край (12\%), Самарская область (12\%).

- по обеспечению электрической энергией, газом и паром, кондиционированию воздуха: Республика Татарстан (15\%), Республика Башкортостан, Самарская область. Пермский край (13\%), Нижегородская область (11\%).

Для определения ведущих видов экономической деятельности в субъектах ПФО был рассмотрен индекс производства по видам экономической деятельности 2019 года в сравнении с 2018 годом.

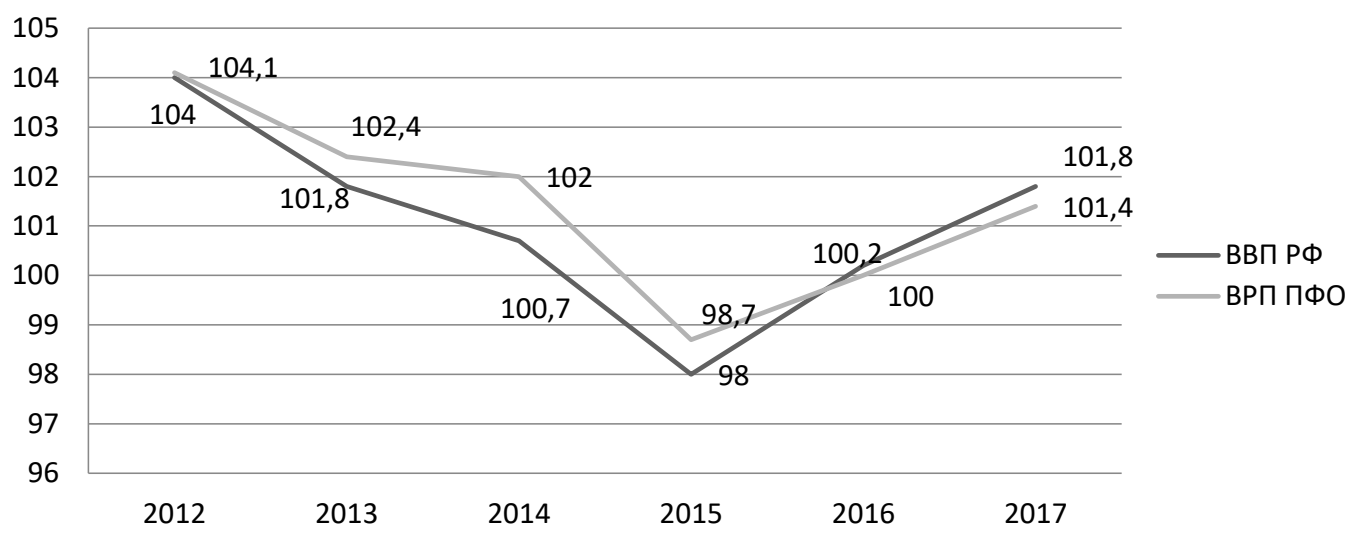

Рисунок 1. Динамика индексов физического объема валового внутреннего продукта РФ и ВРП ПФО за период 2012-2017 гг. (в постоянных ценах; в процентах к предыдущему году) [13] 


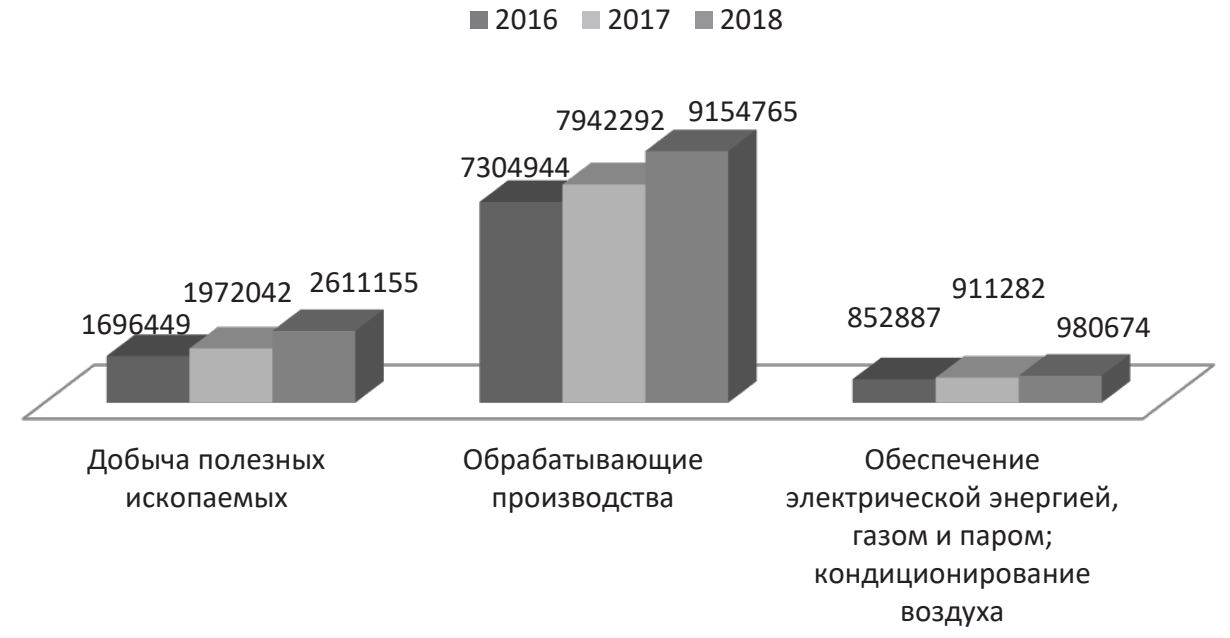

Рисунок 2. Объем отгруженных товаров собственного производства ПФо, выполненных работ и услуг собственными силами по видам экономической деятельности (в фактически действовавших ценах; млн.руб.) [13]

Таблица 1. Индекс производства по видам экономической деятельности январь-декабрь 2019 года, в \% к январю-декабрю 2018 года [13]

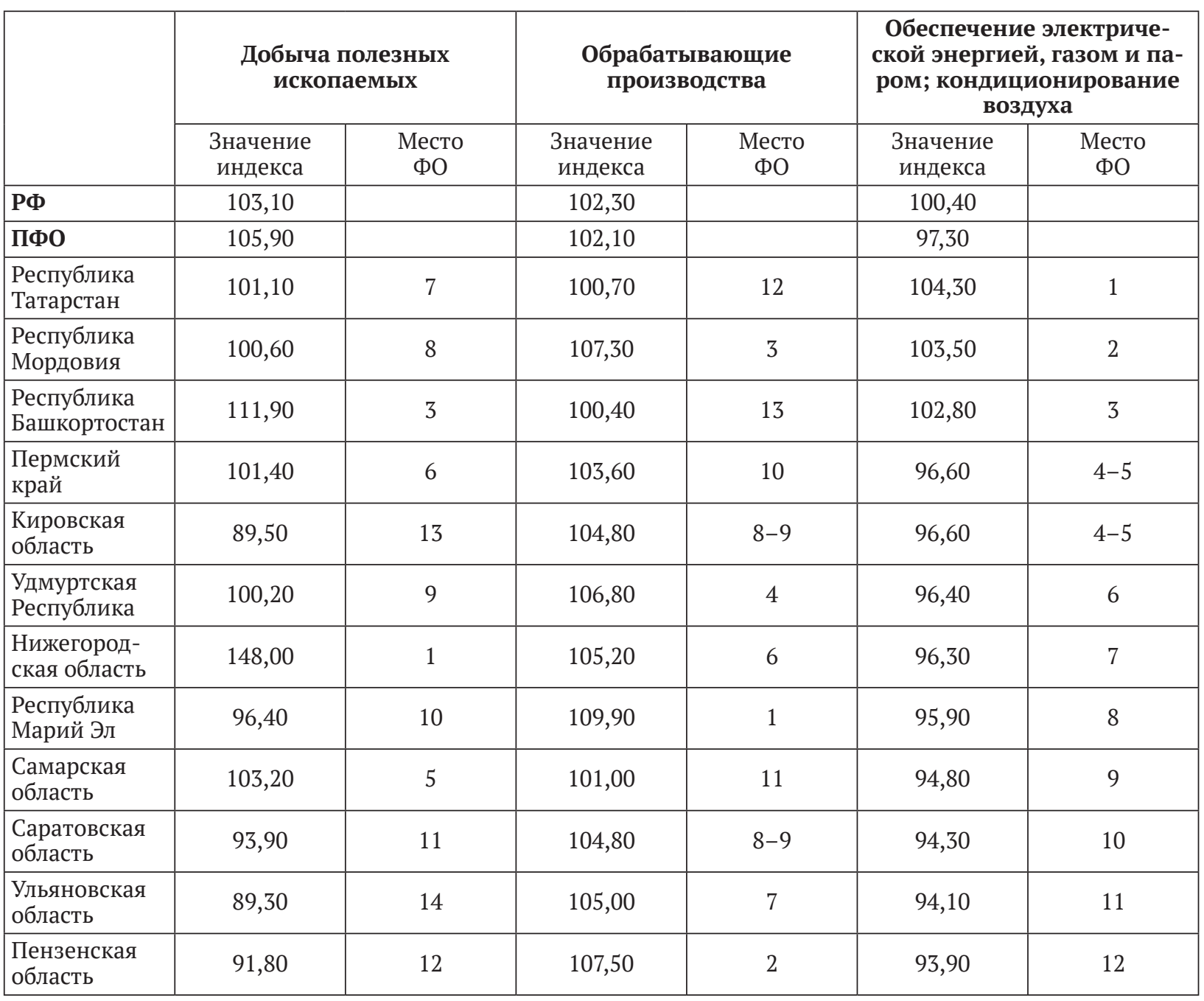


В республике Марий Эл значительный рост отмечен в обрабатывающем производстве. В Пензенской области также положительная динамика отмечается в обрабатывающем производстве. В Республике Башкортостан за 2019 год добыча полезных ископаемых занимает 2 место (111,9\% по сравнению с 2018 г.), наибольший рост отмечен в Нижегородской области (148\% в 2019 г. в сравнении с 2018 г.). Промышленное производство Нижегородской области сосредоточено на машиностроении - автомобилестроении, судостроительных, станкостроительных предприятиях.

В большинстве субъектов локомотивом развития является обрабатывающее производство, что подтверждается объемом отгруженных товаров собственного производства. Структурообразующими отраслями округа являются машиностроение, топливно-энергетический комплекс, особую роль в развитие Приволжья играют предприятия военно-промышленного комплекса. Индекс производительности труда в 2015 и 2018 гг. представлен на рисунке 3.

По результатам изменения индекса производительности труда в 2015 и 2018 гг. наблюдается значительный сдвиг в Оренбургской области (с 98,7\% до 102,7\%), в Нижегородской области (с $98,7 \%$ до 101,6\%), Чувашской области (с 98,9\% до 104,3\%) в 2015 и 2018 годах соответственно. Повышение данного показателя демонстрируют почти все субъекта округа, однако его снижение наблюдается в республике Марий Эл (с 104,2\% до 104\%). Республика Марий Эл не имеет сложившейся специализации, инвестиционные возможности региона ограничены, что в связи с отсутствием базовых конкурентоспособных видов деятельности негативно влияет на занятость населения [11]. Крупнейшие предприятия Республики специализируются в отрасли машиностроения, деревообрабатывающей промышленности. В целях повышения производительности труда в 2019 году субъект вошел в национальный проект «Производительность труда и поддержка занятости».

В 2018 году объем инвестиций в основной капитал в ПФО составил 2467769 млн. руб., что на $2 \%$ выше, чем в 2017 г. в текущих ценах.

В 2018 году рост объема инвестиций отмечен в Пензенской области (на 22\%), в Удмуртской области (на 17\%), в Республике Марий Эл (на 17\%). Снижение показателя наблюдается в Ульяновской области (на 4\%), в Пермском крае (на 3\%).

Анализируя инвестиционную активность за последние 3 года, стоит отметить прирост объема инвестиций в основной капитал в Удмуртской Республике (Прирост на 20\% в 2018 году по сравнению с 2015 годом), Нижегородской области (10\%), Оренбургской области (21\%).

В соответствии с рейтингом инвестиционной активности регионов ПФО наилучшие показатели демонстрирует Республика Татарстан, реализующая 161 проект. Несмотря на развитие инвестиционной активности в субъектах ПФО проблема поиска инвестора сохраняется, в связи с чем, большое число проектов находится на стадии планирования [10]. По объему инвестиций ПФО занимает третье место.

Одним из важных показателей развития 


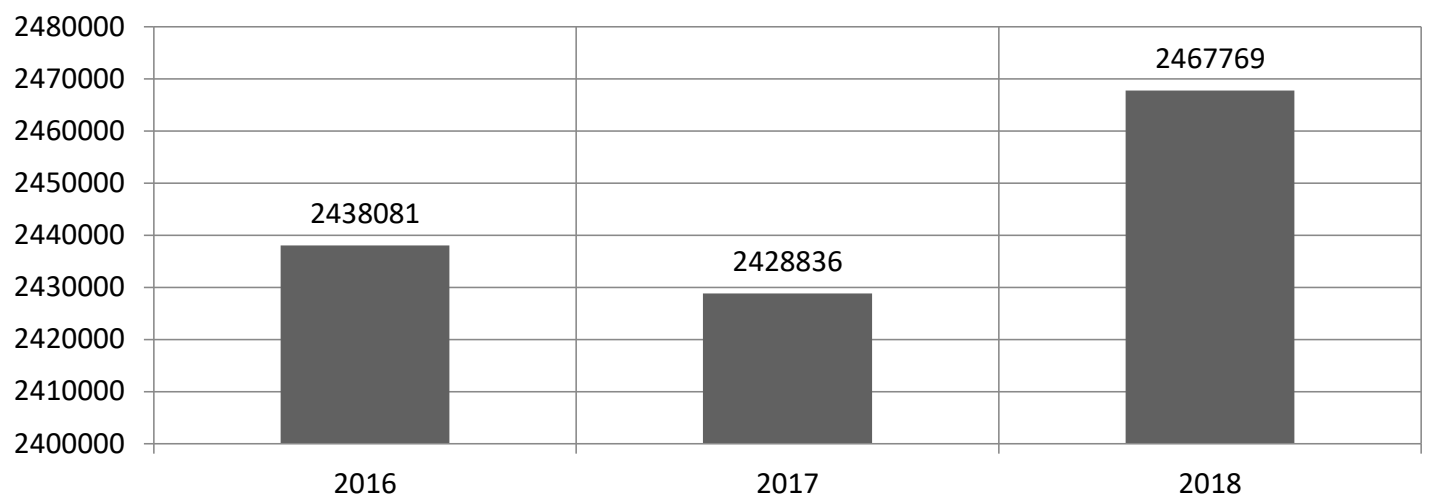

Рисунок 4. Объем инвестиций в основной капитал в ПФО в 2016-2018 гг., млн. рублей [13]

промышленности является наличие высокотехнологичных производств. Эти предприятия отличаются высоким инновационным потенциалом, инвестиционной активностью, созданием высокотехнологичных рабочих мест, что положительно отражается на показателях развития промышленности региона. В разрезе субъектов ПФО проанализирована доля продукции высокотехнологичных и наукоемких отраслей в валовом региональном продукте за 2016-2018 гг.

Около четверти валового регионального продукта ПФО (23,6\% за 2018 год) занимает доля продукции высокотехнологичных и наукоемких отраслей.

Фонд развития промышленности РФ реализует работу по созданию региональных фондов развития промышленности: из 33 региональных фондов 9 приходится на регионы ПФО - Республика Башкортостан, Республика Татарстан, Республика Мордовия, Республика Удмуртия, республика Чувашия; Нижегородская, Пензенская, Ульяновская области, Пермский край.

Развитие высокотехнологичных производств осуществляется в различных секторах. В

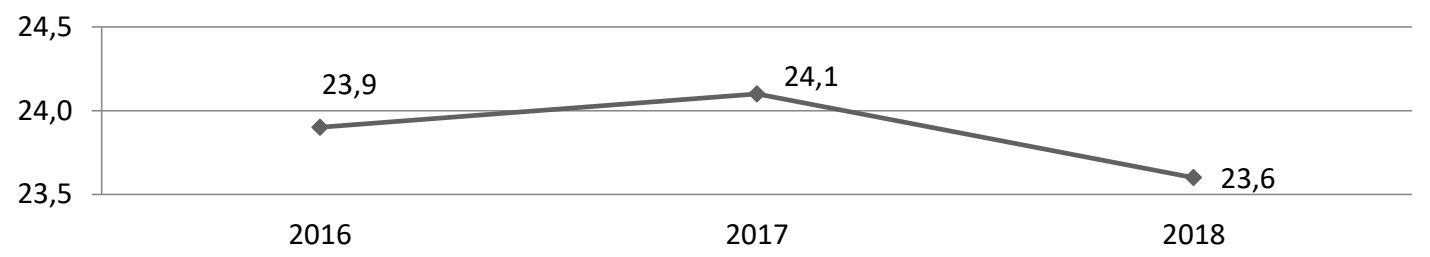

Рисунок 5. Динамика доли продукции высокотехнологичных и наукоемких отраслей в ВРП за период 2016-2018 г. [13]

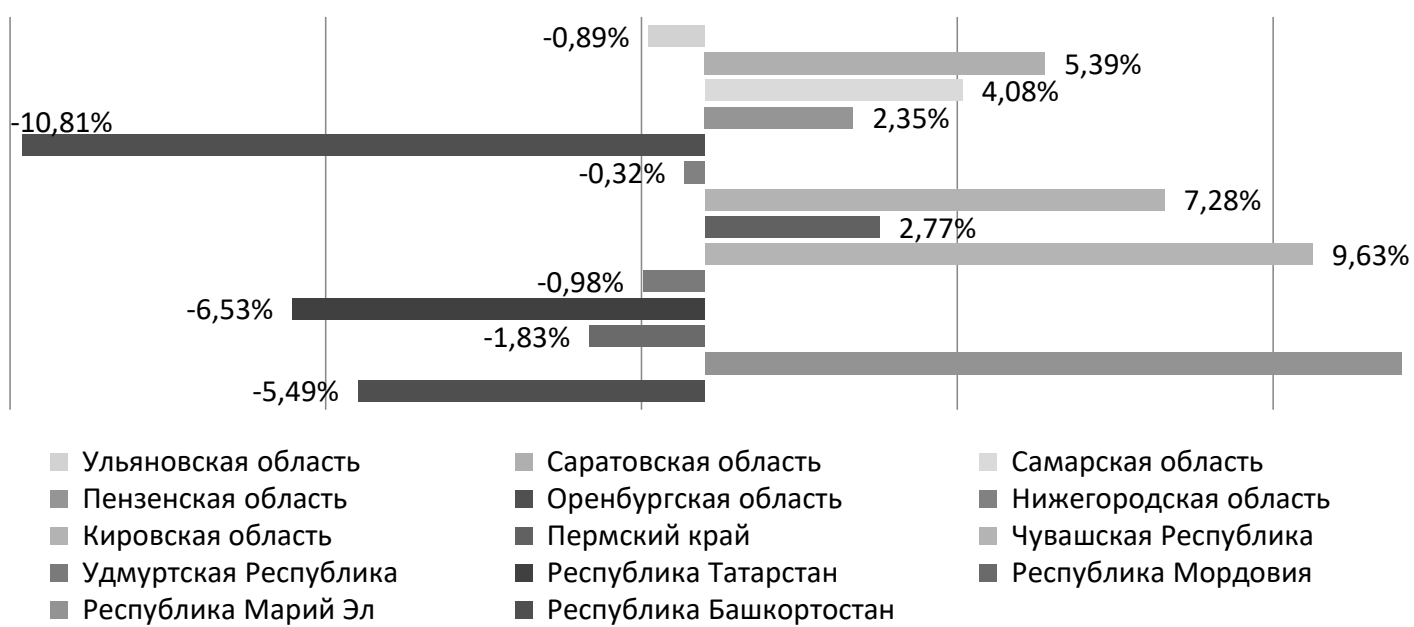

Рисунок 6. Изменение доли продукции высокотехнологичных и наукоемких отраслей в ВРП за период 2016-2018 гг. в субъектах ПФО [13] 
Республике Татарстан - это информационные технологии, нефтехимия, в Самарской области - автомобилестроение, в Нижегородской области - экспорт ядерных технологий. Развитие инновационной инфраструктуры сосредоточено на территориях Республики Татарстан, Республики Чувашии. Республика Марий Эл, повышая долю продукции высокотехнологичных и наукоемких отраслей, увеличивает индекс промышленного производства, что свидетельствует о взаимовлиянии данных показателей.

Одним из важнейших показателей, характеризующим промышленность, рост производства или спад в регионе, является индекс промышленного производства (рисунок 7).

Наибольший рост индекса наблюдается в Республике Марий Эл, Пензенской области, Республике Мордовия, Республике Башкортостан. Наименьшее изменение показателя стоит отметить в Республике Татарстан, Оренбургской, Самарской, Саратовской, Ульяновской областях. Тем не менее, последние, в соответствии с рейтингом инновационной деятельности, превосходят среднероссийские показатели и отличаются значительными инвестициями в инновации [9].

Рассматривая анализируемые показатели как результат промышленной политики регионов ПФО, были выделены группы регионов в зависимости от степени роста либо спада производства. Наиболее эффективно реализуется промышленная политика в Республике Татарстан, Пензенской области, Пермском крае, Республике Башкортостан, Нижегородской области, Уд- муртской Республике. Данные регионы отличаются высоким ВРП по сравнению с другими субъектами ПФО, инвестиционной активностью, значительной долей высокотехнологичной продукции. Во всех регионах наблюдается повышение производительности труда в 2018 году по сравнению с 2015 годом.

На территориях Республик Татарстан и Чувашии сосредоточено наибольшее число инновационных бизнес-инкубаторов, технопарков, что является важным показателем развития промышленности, использования потенциала региона. Динамика индекса промышленного производства ПФО, в целом, в сравнении с другими округами представлена на рисунке 8 .

В соответствии с данными по динамике индекса промышленного производства ПФО и Российской Федерации наблюдается незначительный его рост. По исследованиям Росстата тенденция связана с высоким уровнем налогообложения, небольшим спросом на продукцию промышленности на внутреннем рынке, условиями неопределенности [14].

Проанализировав промышленную политику регионов ПФО, отраслевую структуру, были выявлены проблемы, ограничивающие развитие промышленного потенциала субъектов и округа, в целом. К таким относятся: небольшое число передовых технологий и инвестиционных инновационных проектов; отток капитала в сырьевые регионы; отток населения в более развитые регионы; недостаточная производительность труда; изношенность основных фон-

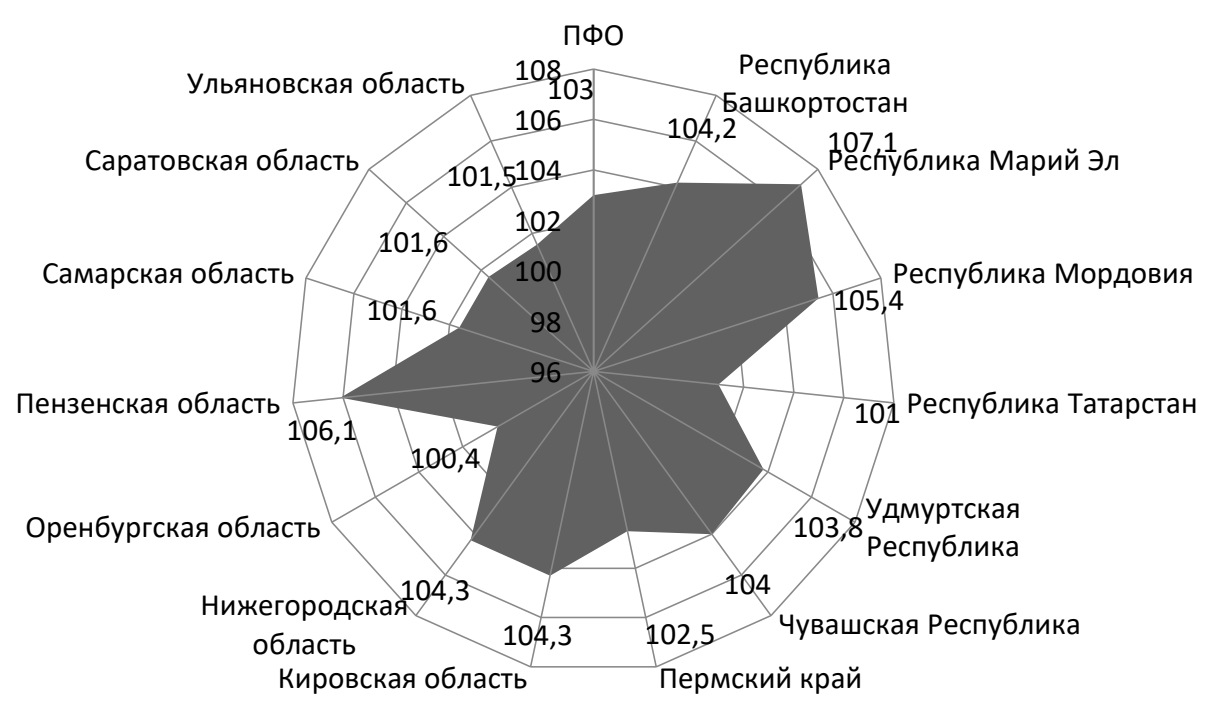

Рисунок 7. Динамика индекса промышленного производства субъектов ПФо (2019 год в процентах к 2018 г.) [12] 


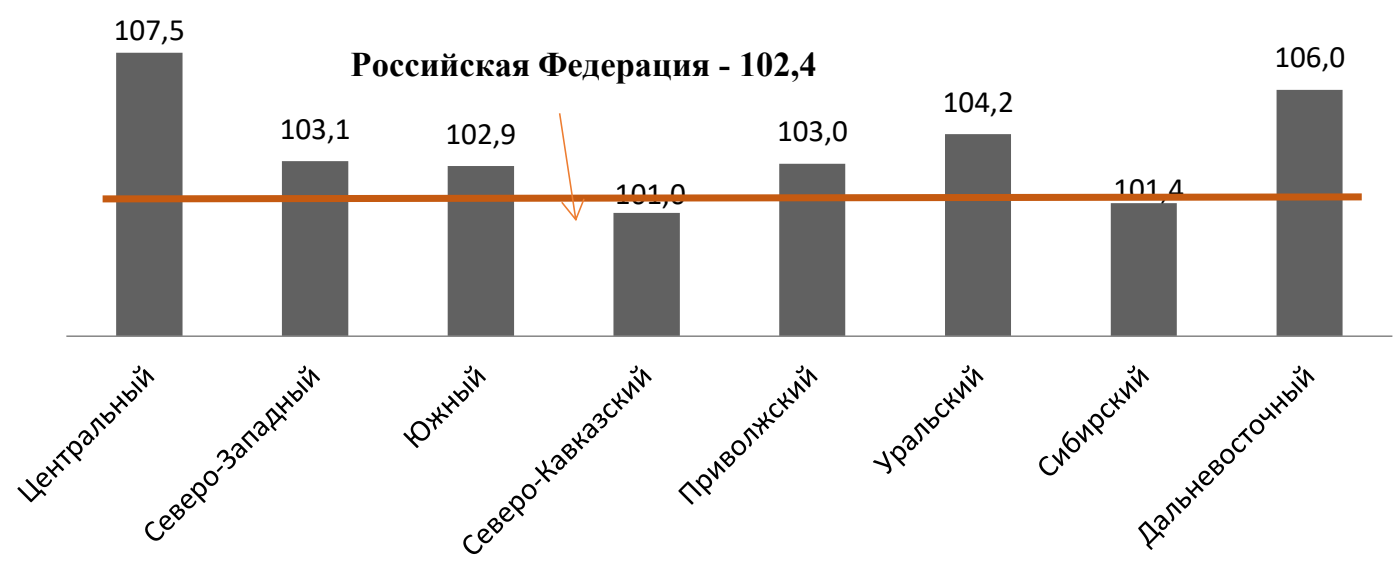

Рисунок 8. Динамика индекса промышленного производства ПФО и Российской Федерации в 2019 году (в процентах к предыдущему году) [13]

дов; недостаточное развитие территориальных производственных систем промышленных парков, кластеров, технополисов); недостаточно сформированная промышленная политика ПФО, ведущая к разноуровневому развитию ее субъектов. В соответствии с проведенным анализом были выявлены основные направления повышения эффективности реализации промышленной политики регионов ПФО.

Данные меры способствуют повышению инвестиционной активности, увеличению производительности труда и рабочих место в регионе. Стоит отметить, развитию региональной промышленной политики может содействовать разработка программ поддержки пограничных с регионом субъектов, что способствует развитию территории, созданию новой совместной инфраструктуры. Проекты, направленные на комплексное освоение территорий, благодаря синергетическому эффекту, способствует ускоренному развитию промышленности и экономики. Таким образом, в целях обеспечения сбалансированного развития сферы промышленности регионов необходима разработка программ в рамках структурной политики, что позволит осуществить переход с экспортносырьевой модели на инновационную, обеспечить развитие производственного потенциала в различных отраслях промышленности. Также разнонаправленная организация производства, усиление активности вызывает необходимость разработки стратегических подходов в управлении развитием хозяйствующих субъектов региона, адаптации к изменениям с учетом ресурсных ограничений, влияющих на уровень использования потенциала предприятий.

Таблица 2. Первоочередные мероприятия по развитию промышленности субъектов ПФО

\begin{tabular}{|c|c|c|}
\hline Группа & Группа регионов & Мероприятия развития промышленности \\
\hline \multirow[t]{4}{*}{ Группа 1} & Пермский край & \multirow{4}{*}{$\begin{array}{l}\text { Мероприятия по развитию институциональ- } \\
\text { ных факторов, обеспечивающих развитие } \\
\text { региональных производственных систем, } \\
\text { наращивание потенциала региона }\end{array}$} \\
\hline & Республика Татарстан & \\
\hline & Нижегородская область & \\
\hline & Республика Башкортостан & \\
\hline \multirow[t]{6}{*}{ Группа 2} & Самарская область & \multirow{6}{*}{$\begin{array}{l}\text { Мероприятия по развитию региональной } \\
\text { институциональной среды, ориентированной } \\
\text { на повышение инвестиционной активности } \\
\text { региона, роста объема производства }\end{array}$} \\
\hline & Оренбургская область & \\
\hline & Чувашская Республика & \\
\hline & Пензенская область & \\
\hline & Удмуртская Республика & \\
\hline & Ульяновская область & \\
\hline \multirow[t]{4}{*}{ Группа 3} & Республика Мордовия & \multirow{4}{*}{$\begin{array}{l}\text { Мероприятия, направленные на создание } \\
\text { условий развития промышленности региона, } \\
\text { повышения инвестиционной активности, вы- } \\
\text { пуск высокотехнологичной продукции }\end{array}$} \\
\hline & Саратовская область & \\
\hline & Республика Марий Эл & \\
\hline & Кировская область & \\
\hline
\end{tabular}


В заключении отметим, что основой формирования промышленной политики, ориентированной на современные требования инновационного развития, является высокотехнологичное производство, что подтверждается зависимостью показателей в регионах Приволжского федерального округа. Учет специфики каждого субъекта позволит создать необходимые условия для сбалансированного развития Приволжского федерального округа.

\section{Библиографический список}

1. Федеральный закон от 31 декабря 2014 г. N 488-Ф3 «О промышленной политике в Российской Федерации» (с изменениями и дополнениями)

2. Постановление Правительства РФ «Об утверждении государственной программы Российской Федерации «Развитие промышленности и повышение ее конкурентоспособности» (с изменениями и дополнениями) от 15 апреля 2014 г. N 328

3. Закон от 25.12.2015 № 206-3 «О промышленной политике в Нижегородской области (с изменениями на 24 декабря 2019 года)»

4. Закон Республики Мордовия от 22.12.2015 № 99-3 «О промышленной политике в Республике Мордовия (с изменениями на 20 сентября 2018 года)»)

5. Закон Республики Татарстан от 21.04.2016 № 24-3РТ «О промышленной политике в Республике Татарстан (с изменениями на 7 мая 2020 года)»

6. Закон Республики Башкортостан от 01 декабря 2015 года N 294-3 «О промышленной политике в Республике Башкортостан (с изменениями на 4 февраля 2020 года)»

7. Дубынина Т.Г., Малахов В.А. Анализ тенденций регионально-отраслевой структуры экономики субъектов Российской Федерации // Проблемы прогнозирования - 2014. - № 3(144). - c.96-107

8. Маковеев В.Н. Управление инновационной деятельностью в обрабатывающей промышленности: региональный аспект // Управление инновационной деятельностью в обрабатывающей промышленности: региональный аспект [Текст]: монография / В. Н. Маковеев, Е. С. Губанова.- Вологда: ИСЭРТ РАН, 2015.- 166 с.

9. Галушко М.В., Дедеева С.А., Иневатова О.А.Инновационная деятельность региона: основные проблемы и перспективы развития (на примере Приволжского федерального округа) // Креативная экономика.2019. - Том 13. - № 1.- С.169-182. Информационный портал инвестиционных проектов, реализуемых в России.- Электронный ресурс. - URL [https://investprojects.info/] (дата обращения: 25.04.2020)

10. Коломейцев Э. М. Федеральные округа в России: уникальный опыт административно-территориального устройства государства.- Электронный ресурс URL [https://cyberleninka.ru/article/n/federalnye-okrugav-rossii-unikalnyy-opyt-administrativnoj-territorialnogo-ustroystva-gosudarstva/viewer] (дата обращения: 25.04.2020)

11. Сарычева Т.В., Бакуменко Л.П. О статистических подходах к оценке отраслевой структуры занятости региона // Вестник НГУЭУ.- 2015. Электронный ресурс URL [https://nsuem.elpub.ru/jour/article/viewFile/596/487] (дата обращения: 25.04.2020)

12. Отчет по региональному сравнению за январь-декабрь 2019 года.- Электронный ресурс. - URL [https:// economy.bashkortostan.ru/dejatelnost/makrojekonomika/analiz-sotsialno-ekonomicheskogo-razvitiya-rb/ analiticheskaya-spravka-po-regionalnomu-sravneniyu/] (дата обращения: 20.05.2020)

13. Федеральная служба государственной статистики.- Электронный ресурс - URL [https://www.gks.ru/ folder/11186?print=1] (дата обращения: 25.04.2020)

14. Динамика промышленного производства в России: опережающий рост добывающего сектора. Электронный ресурс - URL: [https://ac.gov.ru/files/publication/a/23451.pdf] (дата обращения: 20.06. 2020) 